\section{SOI: $1.1 /$ TAS $\quad$ DOI: $10.15863 /$ TAS International Scientific Journal Theoretical \& Applied Science}

p-ISSN: 2308-4944 (print) e-ISSN: 2409-0085 (online)

Year: $2018 \quad$ Issue: 09 Volume: 65

Published: $30.09 .2018 \quad$ http://T-Science.org

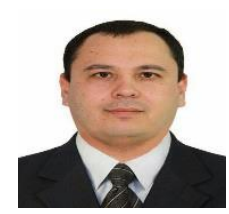

Jobir Baxtiyorovich Mallabayev researcher of

"Corporate governance" department, Tashkent state university of economics, Tashkent, the Republic of Uzbekistan

SECTION 31. Economic research, finance, innovation, risk management.

\title{
APPLICATION OF FOREIGN EXPERIENCE OF CORPORATE GOVERNANCE IN UZBEKISTAN
}

\begin{abstract}
This article provides examples of the main features of the formation of corporate governance models that are used in the world, an analysis of the strengths and weaknesses of management principles in Russian companies to determine which of them is the best model and whether it can be adapted to the various economies of most countries. It also examines the practice of corporate governance in Uzbekistan, compares the Western model of corporate governance with other counterparts. Since literature does not specifically define the notion of "corporate governance" and as long as there can not be a general method based on a comparative study, most authors view each management model as specific, appropriate for each country.

Key words: corporate governance, globalization, model, practice, system.

Language: English

Citation: Mallabayev JB (2018) APPLICATION OF FOREIGN EXPERIENCE OF CORPORATE GOVERNANCE IN UZBEKISTAN. ISJ Theoretical \& Applied Science, 09 (65): 352-357.

Soi: http://s-o-i.org/1.1/TAS-09-65-52 Doi: crossef https://dx.doi.org/10.15863/TAS.2018.09.65.52
\end{abstract}

\section{INTRODUCTION}

In the current conditions of globalization, we can no longer talk about increasing organizational values, ignoring the interests of shareholders, employees, business partners, etc. Such interests can conflict, leading to internal conflicts with subsequent negative impact on the organization's activities. To avoid such discrepancies, responsible behavior on the part of managers is increasingly necessary, which in fact means adopting a corporate governance model. Corporate governance is defined as a system of management and control of the organization, in accordance with the principles and best practices in this area. At the company level, it seeks to structure the distribution of powers and responsibilities between shareholders, directors and management [1]. Today this concept is used to describe the actions of managers, management methods, management in states, world organizations, and enterprises. Basically, it is aimed at how to balance the strength of various factors in decision-making and control and implement tools for both shareholders and other stakeholders in the enterprise's capital. Corporate governance includes rules, measures and appropriate control mechanisms through which shareholders can control the decisions of managers, and partners can be monitored and motivated. Such a system in a modern business environment should initiate and support research and development activities, promote social stability by creating human as well as cultural capital [2]. The issue of corporate governance is clearly international in nature and is closely related to the globalization of the financial and commodity sectors and the cross-border movement of capital. Accordingly, the discussion of the current state and future development of corporate governance should not be limited to national borders.

\section{LITERATURE REVIEW}

With the advent of the late nineteenth and early twentieth centuries. large industrial enterprises corporations - and the development of the joint-stock form there was a separation of the property right from the management of this property. The shareholders of the corporation are legally shareholders who have different number of shares. Direct management of the corporation is carried out by employees (top managers), who may not own any shares. This creates a conflict of interest. Each of the parties pursues its goals: shareholders are interested in the growth of stock prices, increase in dividends; top managers want to receive high salaries, bonuses, social package, solid position. In order to resolve the conflict of interests, it became necessary to create rules that were equally recognized and respected by 
both sides, which led to the emergence of corporate governance.

Among the Uzbek scientists Berkinov BB, Hodiev B.Yu., Hoshimov AA, Suyunov DX, Hamidullin MB, Zaynutdinov Sh.N., Rahimova DN, Nurimbetov R. and others have been studied by the effectiveness of the organizational and economic mechanism of formation, developmental characteristics of corporate governance in our country [1]. Also Berkinov B.B., Hodiev B.Yu., Khoshimov AA, Suyunov D.X., Hamidullin M.B., Zaynutdinov Sh.N., Rakhimova D.N., Nurimbetov R. and others have investigated the effectiveness of the organizational and economic mechanism of formation, developmental characteristics of corporate governance in our country [10].

\section{CORPORATE GOVERNANCE MODELS: FOREIGN EXPERIENCE}

In the world practice of corporate governance of different countries, the system of management and mutual relations between all participants in the process is determined by numerous external and internal factors. These include factors not only of an economic nature, but also a set of national values, cultural characteristics, attitude of citizens of the state where corporate structures function. In the article the author asks the question: is there a Russian model of corporate governance, what are the distinctive and unique characteristics of it? It is customary to single out the Anglo-Saxon, Japanese, German and family models of corporate governance. In the Anglo-Saxon model of corporate governance (Great Britain, USA, New Zealand, Australia), the market is characterized by a very high degree of dispersion of corporate equity. Savings of the population are formed by investing in securities. Thus, the bulk of corporate capital owners are private institutional investors who are willing to take risks and are oriented toward earning an income in the short term. The role of banks in financing corporations is negligible, the main source of financing for companies is the mission of securities. At the same time, legislation and exchange rules require the disclosure of financial information by companies, which provides tight control over the management of enterprises [5]. The German model (Germany, Austria, the Netherlands, Scandinavian countries, Central European countries) is based on the principle of social interaction: the parties interested in the activities of the corporation have the right to participate in the process of taking managerial solutions. [6]

The main difference between the German model and the Anglo-Saxon model is the closed system of corporate governance, which is primarily carried out by banks. The German model is characterized by a high level of concentration of share capital, private investors own shares of corporations in a smaller amount. In addition, the German model is characterized by the practice of cross-ownership of shares, in which two enterprises may be shareholders of each other. The main purpose of cross-ownership is to provide a means of protection of property and resources and of the various companies and investment structures. The result of this practice is a ramified system of interrelated business groups and holdings, whose center is the banks that determine the overall policy of business groups. Within the framework of this model, the interests of the maximum number of stakeholders are taken into account in the decision-making process. In this case, a low degree of corporate transparency is observed. The role of the stock market in the financing of enterprises is negligible [7]. The basis of the Japanese model is the principle of interdependence and social cohesion. Around six of the country's largest banks, groups of interconnected companies have been formed (direct, shorter, and torn enterprises). This model is characterized by the formation around the major banks of financial and industrial groups. The bank provides financing for the companies belonging to the group. The possibility of acquiring these companies by thirdparty market participants is virtually impossible. As a result, the Japanese model (as well as the German one) is characterized by a high level of concentration of ownership among large and medium shareholders and cross ownership of the shares of the group companies. A distinctive feature of the Japanese model is the formation of personal relationships in the management environment, which involves the sharing of knowledge and the intensive use of joint knowledge and experience [ 8]. The family model of corporate governance is applied in many countries, but the most widespread in Italy, Sweden and France. The management of the enterprise is carried out by members of the same family, corporate capital is distributed primarily through family channels. Thus, the family controls the business completely. A family holding company, as a rule, controls a number of interrelated companies. The source of the additional capital of a family corporation is sometimes the means of investors, but they do not receive the majority of votes in the companies of the family group. Thus, the powers of ownership and control are concentrated in the hands of a narrow group of individuals.

The formation of corporate governance is influenced by the degree of development of the stock market and the principal distribution of shares entering the open sale $[9,10]$. Currently, there are 4 models of corporate governance: 1 . American model has developed in the US, Canada, Britain, Australia, New Zealand. It is typical for it that $20-30 \%$ of the shares are immobile, that is, they permanently settle in the hands of a limited number of owners forming a controlling stake, and $70-80 \%$ of shares are mobile, 


\begin{tabular}{|c|c|c|c|c|c|c|}
\hline Impact Factor: & $\begin{array}{l}\text { ISRA (India) } \\
\text { ISI (Dubai, UAE } \\
\text { GIF (Australia) } \\
\text { JIF }\end{array}$ & $\begin{array}{l}=1.344 \\
=0.829 \\
=0.564 \\
=1.500\end{array}$ & $\begin{array}{l}\text { SIS (USA) } \\
\text { PИНЦ (Russia) } \\
\text { ESJI (KZ) } \\
\text { SJIF (Morocco }\end{array}$ & $\begin{array}{l}=0.912 \\
=0.156 \\
=4.102 \\
=\mathbf{5 . 6 6 7}\end{array}$ & $\begin{array}{l}\text { ICV (Poland } \\
\text { PIF (India) } \\
\text { IBI (India) }\end{array}$ & $\begin{array}{l}=6.630 \\
=1.940 \\
=4.260\end{array}$ \\
\hline
\end{tabular}

sold on the stock market and change their owners; 2 . The European model is typical for the countries of Central Europe and Scandinavian countries. It is characterized by the concentration of $70-80 \%$ of the shares of permanent shareholders, as well as the receipt of the remaining $20-30 \%$ of shares in free sale, which is regarded by investors as an object of temporary placement of funds; 3 . The Japanese model developed in the post-war period in Japan. The model was formed on the basis of financial and industrial groups. It is characterized by complete secrecy and bank control, which reduces the influence of managers on decision-making; 4. The family model is present practically in all countries of the world, where the management of the corporation is carried out by members of the same family. Historically, it originated earlier, therefore it is the first model of corporate governance. The main difference between these models is that a different role is assigned to the stock market. The first model admits that a new controlling stake can be formed from the traded shares in the market, that is, in this case there will be a strong dependence on the stock market situation. In subsequent models, the value of the stock market is decreasing. Comparative characteristics of corporate governance models are presented in Table 1.

\section{Comparative characteristics of corporate governance models}

Table 1.

\begin{tabular}{|c|c|c|c|c|}
\hline Characteristics & American model & European model & Japanese model & Family model \\
\hline $\begin{array}{l}\text { Countries in } \\
\text { which }\end{array}$ & $\begin{array}{l}\text { USA, Canada, Great } \\
\text { Britain, Australia, } \\
\text { New Zealand }\end{array}$ & $\begin{array}{l}\text { Countries of } \\
\text { Central Europe, } \\
\text { Scandinavian } \\
\text { countries }\end{array}$ & $\begin{array}{l}\text { Japan, } \quad \text { South } \\
\text { Korea }\end{array}$ & In all countries \\
\hline $\begin{array}{l}\text { Distribution of } \\
\text { shares }\end{array}$ & $\begin{array}{l}20-30 \% \text { of shares } \\
\text { belong to permanent } \\
\text { shareholders, } 70-80 \% \\
\text { of shares are sold on } \\
\text { the stock market }\end{array}$ & $\begin{array}{l}70-80 \% \text { of shares } \\
\text { belong to } \\
\text { permanent } \\
\text { shareholders, 20- } \\
30 \% \text { of shares are } \\
\text { sold in the stock } \\
\text { market }\end{array}$ & $\begin{array}{l}\text { Cross ownership } \\
\text { of shares within } \\
\text { one financial and } \\
\text { industrial group - } \\
95 \%, 5 \% \text { of } \\
\text { shares from } \\
\text { foreign investors }\end{array}$ & $\begin{array}{l}90 \% \text { of the shares } \\
\text { belong to the same } \\
\text { family members, } 10 \% \\
\text { belong to external } \\
\text { investors }\end{array}$ \\
\hline $\begin{array}{l}\text { Impact of the } \\
\text { stock market }\end{array}$ & Strong & Weak & Insignificant & Minor \\
\hline $\begin{array}{l}\text { The influence of } \\
\text { the state on } \\
\text { corporate } \\
\text { governance }\end{array}$ & Weak & Strong & Strong & Weak \\
\hline $\begin{array}{l}\text { Management of } \\
\text { the corporation }\end{array}$ & hired top managers & $\begin{array}{l}\text { shareholders, top } \\
\text { managers, staff, } \\
\text { representatives of } \\
\text { banks, public } \\
\text { organizations }\end{array}$ & $\begin{array}{l}\text { top managers, } \\
\text { banks, } \\
\text { shareholders }\end{array}$ & $\begin{array}{l}\text { shareholders of the } \\
\text { same family }\end{array}$ \\
\hline $\begin{array}{l}\text { Features of the } \\
\text { model }\end{array}$ & $\begin{array}{l}\text { high level of self- } \\
\text { regulation, } \\
\text { observance } \\
\text { normative legal acts, } \\
\text { protection of minority } \\
\text { investors }\end{array}$ & $\begin{array}{l}\text { High internal } \\
\text { control over } \\
\text { financial results }\end{array}$ & bank control & $\begin{array}{l}\text { The internal control is } \\
\text { exercised by } \\
\text { shareholders, the state } \\
\text { exercises external } \\
\text { control through legal } \\
\text { acts }\end{array}$ \\
\hline $\begin{array}{l}\text { Disadvantages of } \\
\text { the model }\end{array}$ & $\begin{array}{l}\text { probability of conflict } \\
\text { of interests between } \\
\text { shareholders and top } \\
\text { managers, orientation } \\
\text { to short-term interests } \\
\text { of investors }\end{array}$ & $\begin{array}{l}\text { The bank is both } \\
\text { shareholders and } \\
\text { creditors of the } \\
\text { corporation, } \\
\text { banks have the } \\
\text { ability to conduct } \\
\text { share } \\
\text { manipulation, } \\
\text { limited to free } \\
\text { competition }\end{array}$ & $\begin{array}{l}\text { Banks are } \\
\text { simultaneously } \\
\text { shareholders and } \\
\text { creditors of the } \\
\text { corporation, } \\
\text { banks have the } \\
\text { ability to conduct } \\
\text { share } \\
\text { manipulation, } \\
\text { limited freedom } \\
\text { of competition }\end{array}$ & $\begin{array}{l}\text { For the development of } \\
\text { the corporation, internal } \\
\text { sources of financial } \\
\text { resources are used, the } \\
\text { lack of financing can } \\
\text { restrain the technical } \\
\text { and technological } \\
\text { development of the } \\
\text { corporation }\end{array}$ \\
\hline
\end{tabular}


The American model of corporate governance is based on the peculiarities of national joint-stock ownership, which presupposes the presence of a large number of owners who do not pretend to participate in the board of directors, and also at a high level of liquidity of shares traded on the stock market. It is focused on attracting capital from external sources. Forms of market control are mergers, acquisitions and redemption of shares. The European model of corporate governance took as a basis the experience of corporate governance in Germany. In the Japanese model, the corporate governance system is built around a key bank and a financial and industrial network. The bank is the main shareholder of the corporation, as well as provides loans, issues bonds, shares, performs settlements and consulting operations. In this case, the practice of cross-ownership of the shares of companies belonging to this group is supported. The success of not only one company but the entire financial and industrial group is important, which has a positive impact on the development of the entire national economy. The family model of corporate governance is the most closed, since the creation, development of the corporation is carried out by members of the same family. It can be attributed to the oldest model, as it arose much earlier than other models. Traditions of the family in this case are a guarantee of quality. But the problems of attracting additional resources, developing and introducing new technologies, new products, development of new sales markets require interaction with different organizations in different cities and countries. Therefore, this model has certain internal limitations. In general, the system of corporate governance leads to the following positive results: 1 . contributes to the increase in the market value of the corporation; 2 . Increases investment attractiveness; 3 . reduces the cost of lending; 4. Promotes the attraction of longterm investments. In the context of globalization, transnational corporations generate and accumulate huge flows of investment capital, so the problem of corporate governance is already reaching the state and international levels. Since the 90 s of the XX century. the problem of protecting the rights and interests of investors comes to the fore. With the support of governments and international organizations such as the World Bank, the European Bank for Reconstruction and Development, the International Finance Corporation, the Organization for Economic Co-operation and Development and other entities, the development and implementation of national corporate governance codes is under way. Problems in the largest companies in the US, UK and Canada have served as an impetus for the development of corporate governance codes. Representatives of stock exchanges, corporations, institutional investors, associations of directors and corporate managers, associations for the protection of investors' rights worked on them.

The first codes of corporate governance were used by other countries to develop their national codes of corporate governance. By the end of 2002, about 90 codes of corporate governance had been developed and adopted in various countries and companies.

The most common national codes regulating corporate governance are presented in Table 2 . Despite the differences in the recommendations of corporate codes of different countries, they all recommend paying attention to the following aspects: 1. Preparation and holding of a general meeting of shareholders; 2. Board of Directors: election and provision of effective activities; 3 . executive body (board, general director); 4 . Disclosure of information about the activities of the corporation. The rules prescribed in the corporate governance code are most often recommendatory and mandatory only for companies participating in listing on the London and Toronto exchanges. But compliance with the rules of the code may be part of the requirements for disclosure of information about the corporation.

\section{DOMESTIC EXPERIENCE OF CORPORATE GOVERNANCE}

Decree of the President of the Republic of Uzbekistan "On Measures to Increase the Role and Value of Private Sector in the Economy of Uzbekistan" of January 24, 2003, and Decree of the Cabinet of Ministers of April 19, 2003 "On Measures to Improve Corporate Governance of Denialized Entities" implementation and improvement.

The introduction of corporate methods and principles in the companies of Uzbekistan is one of the pressing issues of increasing the effectiveness of organizational-organizational organizational and economic mechanism of the corporate governance, development of the company's development strategy, based on the interests of the business.

In the economic literature, the concept of "mechanism" reflects many situations. Therefore, there are many different types of economy. For example, organizational mechanism, economic mechanism, technological mechanism, social mechanism, financial mechanism, innovation mechanism, investment mechanism, infrastructure mechanism, management mechanism, property mechanism, etc.

The introduction of corporate methods and principles in domestic companies is one of the pressing issues of increasing the effectiveness of organizational-economic mechanism of corporate governance and development of the company's development strategy, based on the interests of the business. In the economic literature, the concept of 
"mechanism" reflects many situations. Hence, there are many different types of economy. For example, organizational mechanism, economic mechanism, technological mechanism, social mechanism, financial mechanism, innovation mechanism, investment mechanism, infrastructure mechanism, management mechanism, property mechanism, etc.

The Corporate Governance Mechanism is described by national researchers as follows: "The Corporate Governance Mechanism is a set of elements that promote the company's (or corporation's) social, economic, legal, and organizational relationships that are needed to achieve its goals."

Experts point out that the growth of the construction materials industry in Uzbekistan was attributed to a large volume of capital investments in the modernization of the economy within the framework of medium-term state programs. In particular, the volume of capital investments in the national economy in 2016 has increased by $18 \%$ to about 50 trillion soums. soums.

Thus, the volume of construction works increased, resulting in further increase in demand for construction materials. It should be noted that over half of the produced construction materials belong to the enterprises of Uzstroymaterialy JSC. At present more than 100 kinds of construction materials are being produced at 120 enterprises of the company. They satisfy the domestic demand for building materials.

Cement production in Uzbekistan is increasing every year. It currently supplies not only the country's cement, but also exports to other foreign countries. It accounts for about $76 \%$ of the total volume of industrial construction materials manufactured in our country.

In the future, the production of cement in Uzbekistan increases annually. Its capacity will increase by an average of $3.5 \%$ per year and will amount to $8.9 \mathrm{mln}$. tons of cement. These parameters are defined in our country in the Program of Modernization and Diversification of Production in Structural Change in the Economy for 2015-2019.

Development of medium-term and long-term programs to increase the production of cement products and their economic and technological capacities in the country, the creation of joint ventures with attraction of foreign investments is an urgent problem in this area.

The use of corporate governance in production is of great economic importance for the sustainable macroeconomic development of the country's economy. Therefore, in the early stages of economic reforms, the unreasonable increase of joint-stock companies, their ineffectiveness, the uncertainty of some shareholders, and other factors may prevent the introduction of corporate governance. Therefore, the effective use of the economic mechanism in all types of corporate property depends on the degree of its organizational management.

One of the main ways of development of organizational-economic mechanism of corporate property management in market economy. Under the new economic conditions, the essence of the organizational-economic mechanism of large-scale production based on the forms of corporate property in the market-based production and management process had to radically change. The foreign scientist M.Meskon, the Russian economist, B.Milner, the Uzbek lawyer A.Azizhodzhaev, stated that "large organizations create real conditions for industrial and technological development" [11].

We support this idea and believe that in our country, the process of institutionalization is currently slowing down the introduction of corporate governance practices, not involving the state, noninterference in their activities, and finding solutions to any economic problems. At the same time, the organizational and economic mechanism of the former administration leads to the stagnation.

Corporate governance efficiency is closely linked to the improvement and development of production. On the other hand, it is necessary to clearly define ways to ensure the effectiveness of the organizational and economic mechanism of corporate governance [12]. Improving the effectiveness of corporate governance should be focused on the following objectives:

The level of organizational mechanism development;

Regularly control the production activity, its technological development;

Introduction of corporate culture in corporate production;

Providing reasonable relationships with TOP managers at the level of corporate governance;

Taking care of corporate development tasks through the TOP Manager. [13]

In order to be able to know the effectiveness of corporate governance, it is necessary to correct the methods of calculation of indicators and means of macro and micro level. Because a single macro indicator may contain several micro-indicators.

It is important to ensure that production is linked to the management structure that implements the state economic policy to improve its management efficiency [14]. Only in this case you can achieve productivity and corporate governance efficiency. If such a form of government is ineffective if the economic interest of corporate governance does not correspond to the economic interests of the state.

Summarizing the main results of the issues raised allowed the following conclusions:

The level of organizational and economic mechanism of corporate governance is one of the main tools for regulating the company. Its wellestablished evidence indicates the company's normal 


\begin{tabular}{|c|c|c|c|c|c|c|}
\hline Impact Factor: & $\begin{array}{l}\text { ISRA (India) } \\
\text { ISI (Dubai, UAE } \\
\text { GIF (Australia) } \\
\text { JIF }\end{array}$ & $\begin{array}{l}=1.344 \\
=0.829 \\
=0.564 \\
=1.500\end{array}$ & $\begin{array}{l}\text { SIS (USA) } \\
\text { PИНЦ (Russia) } \\
\text { ESJI (KZ) } \\
\text { SJIF (Morocco) }\end{array}$ & $\begin{array}{l}=0.912 \\
=0.156 \\
=4.102 \\
=2.031\end{array}$ & $\begin{array}{l}\text { ICV (Poland) } \\
\text { PIF (India) } \\
\text { IBI (India) }\end{array}$ & $\begin{array}{l}=6.630 \\
=1.940 \\
=4.260\end{array}$ \\
\hline
\end{tabular}

operation. The organizational and economic mechanism represents the sum of internal and external mechanisms. It works together with macroeconomic and microeconomic indicators.

Correct organization of the organizational and economic mechanism of the company, its impact on the effectiveness of management of the company depends directly on managers and staff qualifications. The higher the degree of their knowledge, the more effective the technology, the management, the better marketing, the better organizational and economic mechanism of the company.

The effectiveness of corporate governance is a key factor in the overall effectiveness of the organizational and economic mechanism of production management. The organizationaleconomic mechanism of corporate governance is critically measuring the effectiveness of corporate governance.

\section{References:}

1. Zakieva N.M. (2013) Corporate Project Management System as a Mechanism for Improving the Efficiency of Innovation Management // Economics and Entrepreneurship. - 2013. - No. 7. - p. 308-311.

2. Itigina AA, Burdenko EV (2013) Questions of terminology: cooperation in foreign and Russian practice // Leasing. - 2013. - No. 11. p. 33-37.

3. Kuvaeva V.D. (2014) Delineation of the concepts of corporate governance, corporate governance and the corporate management system of the organization // Vestnik University (State University of Management). - 2014. - № 17. - p. 211-215.

4. Lobzov A.V. (2015) Without which the corporate project management system does not work // Russian Entrepreneurship. - 2015. - T. 16. - No. 13. - p. 2045-2052. - doi: 10.18334 / rp.16.13.492

5. Tsvetkov V.A. (2011) Corporate business: history and practice. - St. Petersburg: NestorHistory, 2011. - 504 p.

6. Allen F., Zhao M. (2007) The Corporate Governance Model of Japan: Shareholders are not Rulers [Electronic resource] // Finance.wharton.upenn.edu. - 2007. - Mode of access: http://finance.wharton.upenn.edu/ allenf/downl oad/Vita/Japan-CorporateGovernance.pdf

7. (2000) Investor Opinion Study. McKinsey\&Co, 2000.

8. Martynova M., Renneboog L. (2011) Evidence on the international evolution and convergence of corporate governance regulations // Journal of Corporate Finance. - 2011. - Vol. 17. - № 5. - p. 1542

9. Çelik S., Demirtaş G., Isaksson M. (2015) Corporate Bonds, Bondholders and Corporate Governance. - OECD, 2015. - p. 65.

10. Berkinov B.B. (2005) Corporate structures: the fundamentals of creation and management. $\mathrm{T}$.: INB them. Alisher Navoi., 2005, - p.147;

11. Hodiev B. Yu. (2010) Corporate Governance. T.: Economics, 2010, p. Hoshimov A.A. Development prospects of corporations. T .: Finance, 2003, 111 p.

12. Kaplan R.S., Norton D.P. (2006) Alignment: Using the Balances Scorecard to Create CorporateSynergies. Harvard Business Review Press, 2006-320 p.

13. Meskon M. et al. (2007) Fundamentals of Management. M .: Case, 2007, 701.

14. Gerchikova IN (2007) Management M .: UNITY, 2007, $480 \mathrm{p}$.

15. Zaynutdinov Sh.N., Ashurov Z.A. (2010) Corporate Governance. T .: 2010, 92 p. 